\title{
Factors Affecting the Purchasing Behaviour of Consumers in Ernakulam District with Special Emphasis on Bathing Soap
}

\author{
G. Ajai Krishnan and Dr.M. Nandhini
}

\begin{abstract}
In the present day it is very much momentous to know the attitude of consumers and their intentions while selecting a product, especially FMCG products. Researches on purchasing behaviour will surely help out the companies to know more about the consumer's behaviour while choosing a product, so that they can spend their marketing efforts in an effective way. From the preceding researches it is obvious that bathing soap is among the highest penetrated category within the FMCG sector. The present study tries to calculate the factors behind the consumers purchasing behavior towards bathing soaps with special reference to Ernakulam District in Kerala. The study made use of primary and secondary data. A sample of 110 customers from Ernakulam city of Kerala is collected from four super markets by using judgment sampling method. The results explain that customers are motivated to purchase bathing soap because of the, awareness, brand image, word of mouth publicity, advertisement, celebrity, price etc.
\end{abstract}

Keywords--- JEL Code-M31, Consumer Purchasing Behaviour, Bathing Soap Purchasing, Word of Mouth Publicity, Celebrity.

\section{INTRODUCTION}

$\mathrm{I}$ today's aggressive world it's very difficult to outline consumers approach and intentions and shift them to the next level of purchasing process, marketers find it yet more difficult and challenging to break through the chaos of competitive marketing efforts of different companies. Every marketing effort tries to create reachability for their products and attempts to stimulate a lasting reflection in the minds of customers.

Companies does their marketing efforts via television, newspapers, magazines, journals, radio, press, internet, direct selling, hoardings, mailers, contests, sponsorships, posters, events, colours, sounds, visuals, celebrity advertisements etc.

Toilet soap industry is one of the oldest Fast Moving Consumer Goods (FMCG) industries in India.

Soap is a basic material arbitrarily used by the rich and the poor. Since soaps are used both for bathing and washing, it has become an vital and indispensible part of human life.

G. Ajai Krishnan, Research Scholar, Karpagam University, Coimbatore, Tamilnadu.E-mail:ajaikgnair82@gmail.com

Dr.M. Nandhini, Research Guide, Karpagam University, Coimbatore, Tamilnadu.E-mail:nandhini1817@gmail.com

DOI: 10.9756/IJRAS.8150
The present article we are studying more about the factors which affecting the consumers purchasing behavior towards bathing soap. The frequency of using bathing soap might vary according to the individual hygiene practice. Bathing soaps today are far too sophisticated and are available in a wide variety of forms for specific end uses. Now a days the demand for bathing soaps is increasing with the increase in the standard of living, purchasing power of population, urbanization, literacy, growth of media, improvement in transportation and communication networks, growth of super markets, hyper markets and organised retail outlets etc. Presently the multinational companies face competition from the major retail stores who are increasingly introducing own private label brand products.

Consumer behaviour is the study of individuals, groups, or organisations and the processes they use to select, secure, and dispose of products, services, experiences, or ideas to satisfy needs and the impacts that these processes have on the consumer and society.

The marketer therefore tries to understand the needs of different consumers and also tries to understand their different purchasing behaviors which require an in-depth study of the internal and external environment. Consumer purchasing decision depends on perception, self-concept, social and cultural background, age, family lifecycle, attitude, belief, values, motivation, personality, social class and so on.

It also tries to assess influences on the consumer from groups such as family, friends, reference groups, and society in general. Kerala has been witnessing a tremendous social transformation over the past decade to shape a new consumerist state with increased interest in I.T Parks, shopping malls, hyper markets, educational services, medical facilities, tourism etc.

An increase in the working population with higher income, resulting increased living standards even in the rural areas providing better growth prospects and demand for the FMCG sector especially in Ernakulam District.

\section{REVIEW OF LITERATURE}

A Ananda Kumar and S Babu (2014), in their study, 'Factors influencing consumer buying behaviour with special reference to dairy products in Pondicherry State', says that a considerable amount of Brand Switching behaviour is observed among the respondents in case of non-availability of their favourite brands in their stores and also a Retailer role in influencing brand choice is Considerable at this level. 
Khaled Mahmud \& Khonika Gope (2012), revealed in their study, Factors Influencing the extent of brand loyalty of toilet soap users says that while in consuming toilet soaps, people are influenced by family members, product features or availability of soaps in the local stores.

G. Muruganantham and Priom Biswas (2011), in their study, 'Factors Influencing the Buying Behaviour of chocolates', reveals that taste plays a crucial role while selecting a chocolate brand, respondents look for unique taste in the product they choose as compared to the other available products in the market.

Such an emphasis on the unique taste implies that the ingredients of the chocolate are also very important for the consumers. The buying of chocolates is affected by its reach to the consumers and its availability in the market.

Manoj Patwardhan, Preeti Flora and Amit Gupta (2010), in their study, 'Identification of Secondary Factors that Influence Consumer's Buying Behavior for Soaps and Chocolates', revealed that few common characteristics include availability of products to consumer, caution and concern shown by the consumer for product ingredients, budget compatibility of consumer like cost of product, fragrance, shape and seasonal variation and advertisement.

It can also be suggested that media publicity, particularly in the electronic media, plays a significant role in influencing consumer's mind.

Soumya Saha, Munmun Dey and Sumanta Bhattacharyya (2010), in their study, 'Factors Affecting Consumer Buying Behavior of Shoes in Kolkata: A Case Study', reveals that the marketers should emphasize on convenient location of shops and also in maintaining high quality standards to ensure that they gain fame through word-of mouth advertising. They should sell the shoes from exclusive shoe outlets rather than through supermarkets or departmental stores.

Tudor Edu, Iliuță Costel Negricea and Alexandru Ionescu (2010), in their study, 'Consumer Behaviour patterns: Identifying buying motives for cool drinks amongst South Africans under 35 years old', reveals that the research display a complex consumer behaviour pertaining to cool drinks. The respondents showed a tendency towards objective buying decisions but amongst a collection of brands for which a certain degree of loyalty was displayed.

T.Mamatha (2008) in her study 'Post purchase behavior and consumerism' says that consumer behavior is a very complex phenomenon, which needs more efforts to understand, explain and predict.

In order to get a clear understanding of the same, every marketer should realize that consumer behavior is, in fact, an assumption every marketing manager must make, if he plans to market on any basis other than hit-or-miss. Although some individuals find it difficult to make this assumption, one must agree that behavior is not so erratic or mysterious that it defies explanation.

\section{RESEARCH METHODOLOGY}

\section{A. Statement of the Problem}

It is always a superior challenge for the companies to calculate the consumer purchasing behaviour towards different products and especially bathing soaps.

Since on a every day basis various bathing soap companies are coming with pioneering marketing concepts, need arises whether these marketing efforts having any impact on the consumers purchasing behaviour. The present study tries to identify the various factors that leading to the consumers purchasing with special reference to bathing soap consumers.

\section{B. Objectives}

The Primary objective of this study is to find out the factors which affecting the consumer's buying behavior towards bathing soap with special reference to bathing soap customers in Ernakulam District of Kerala. Based on this primary objective, other supporting objectives are set as presented below,

- To identify the demographic profile of the bathing soap customers in Ernakulam District.

- To identify the factors that affecting the selection of a bathing soap by the customers.

C. Sampling Design

Judgment sampling is used for the study.

D. Sampling Size

Sample size was 110 customers from Ernakulam District.

E. Area of Study

The study was conducted at four super markets of Ernakulam District.

F. Period of Study

The study was conducted for a period of two months.

\section{G. Limitation of the Study}

Following are the limitations of the study that future researches should aim to address:

- Questionnaires were distributed in one city in Kerala, so the results might not be same in other parts of Kerala.

- Sample size was fairly normal, which could be increased to gather a more comprehensive view of respondents. 


\section{Results \& Discussion}

Table 1: Table showing the Demographic Profile of the Respondents

\begin{tabular}{|c|c|c|c|}
\hline Demographic Variable & Sub Categorization & No. of Respondents & Percentage \\
\hline \multirow{3}{*}{ Gender } & Male & 39 & $35.5 \%$ \\
\hline & Female & 71 & $64.5 \%$ \\
\hline & Total & 110 & $100 \%$ \\
\hline \multirow{7}{*}{ Age } & $18-25$ & 7 & $6.4 \%$ \\
\hline & $26-33$ & 18 & $16.4 \%$ \\
\hline & $34-41$ & 38 & $34.5 \%$ \\
\hline & $42-49$ & 29 & $26.4 \%$ \\
\hline & $50-57$ & 13 & $11.8 \%$ \\
\hline & 58 and above & 5 & $4.5 \%$ \\
\hline & Total & 110 & $100 \%$ \\
\hline \multirow{3}{*}{ Marital Status } & Single & 26 & $23.6 \%$ \\
\hline & Married & 84 & $76.4 \%$ \\
\hline & Total & 110 & $100 \%$ \\
\hline \multirow{5}{*}{ Education } & Matric & 20 & $18.2 \%$ \\
\hline & Higher Secondary & 27 & $24.5 \%$ \\
\hline & Graduation & 41 & $37.3 \%$ \\
\hline & Post Graduation & 22 & $20 \%$ \\
\hline & Total & 110 & $100 \%$ \\
\hline \multirow{5}{*}{ Occupation } & Professional & 18 & $16.4 \%$ \\
\hline & Businessman & 10 & $9.1 \%$ \\
\hline & Salaried Person & 45 & 40.9 \\
\hline & Housewife & 37 & 33.6 \\
\hline & Total & 110 & $100 \%$ \\
\hline \multirow{7}{*}{ Income (in Lakhs) } & $<=1$ & 5 & $4.5 \%$ \\
\hline & $1.1-2$ & 14 & $12.7 \%$ \\
\hline & $2.1-3$ & 37 & $33.6 \%$ \\
\hline & $3.1-4$ & 28 & $25.5 \%$ \\
\hline & $4.1-5$ & 17 & $15.5 \%$ \\
\hline & Above 5 & 9 & $8.2 \%$ \\
\hline & Total & 110 & $100 \%$ \\
\hline \multirow{5}{*}{ Family Size } & 2 members & 7 & $6.4 \%$ \\
\hline & 3 members & 32 & $29.1 \%$ \\
\hline & 4 members & 47 & $42.7 \%$ \\
\hline & 5 or more & 24 & $21.8 \%$ \\
\hline & Total & 110 & $100 \%$ \\
\hline
\end{tabular}

Source: Survey Data

Table 1 reveals the demographic profile of the respondents. That is,

1. $35.5 \%$ respondents were male and $64.5 \%$ respondents were female.

2. $34.5 \%$ respondents fall under the age group of between 34-41 years, 26.4\% respondents fall under the age group of between $42-49$ years, $16.4 \%$ of respondents fall under the age group of 26-33 years, $11.8 \%$ of respondents fall under the age group of 50 $57,6.4 \%$ of respondents fall under the age group of $18-25$ and $4.5 \%$ respondents fall under the age group of 58 and above years.

3. $76.4 \%$ respondents were married, and $23.6 \%$ respondents were single.

4. $37.3 \%$ respondents were graduate, $24.5 \%$ were higher secondary post graduate, $20 \%$ were post graduate, and $18.2 \%$ were matric.

5. $40.9 \%$ respondents were salaried persons, 33.6\% were housewives, $16.4 \%$ were professionals, and $9.1 \%$ respondent's belonged to businessmen category.

6. $4.5 \%$ respondents belongs to the income bracket of below less than or equal to 1 lakhs, $12.7 \%$ respondents were from the income group of 1.1-2 lakhs, 33.6\% respondents were from the income group of $2.1-3$ lakhs, 25.5\% respondents were from the income group of $3.1-4$ lakhs, $15.5 \%$ respondents were from the income group of 4.1-5 lakhs, and $8.2 \%$ is having monthly income above 5 lakhs.

7. $6.4 \%$ respondents having a family size of 2 members, 29.1\% having a family size of 3 members, $42.7 \%$ having a family size of 4 members, and $21.8 \%$ respondents family consists of 5 members or more.

Table 2: Table Showing the Factors Affecting the Selection of a Bathing soap by the Respondents

\begin{tabular}{|l|l|l|}
\hline \multicolumn{1}{|c|}{ Characteristics } & Frequency & Percentage \\
\hline Quality & 11 & $10 \%$ \\
\hline Brand Name & 18 & $16.4 \%$ \\
\hline Advertisement & 13 & $11.8 \%$ \\
\hline Celebrity & 7 & $6.4 \%$ \\
\hline Fragrance & 6 & $5.5 \%$ \\
\hline Price & 9 & $8.2 \%$ \\
\hline Word of Mouth Publicity & 16 & $14.5 \%$ \\
\hline Sales Promotion & 5 & $4.5 \%$ \\
\hline Awareness & 20 & $18.2 \%$ \\
\hline Packaging & 2 & $1.8 \%$ \\
\hline Availability & 3 & $2.7 \%$ \\
\hline Total & 110 & $100 \%$ \\
\hline
\end{tabular}

Source: Survey Data

Table 2 reveals the factors that affecting the selection of a bathing soap by the respondents. That is; $18.2 \%$ of 
respondents is of the opinion that awareness is the main factor which affects the selection of a bathing soap followed by $16.4 \%$ of respondent selected the bathing soap because of brand name followed by various factors like word of mouth publicity (14.5\%), advertisement (11.8\%), quality (10\%), price (8.2\%), celebrity $(6.4 \%)$, fragrance $(5.5 \%)$, sales promotion (4.5\%), availability (2.7\%), packaging (1.8\%).

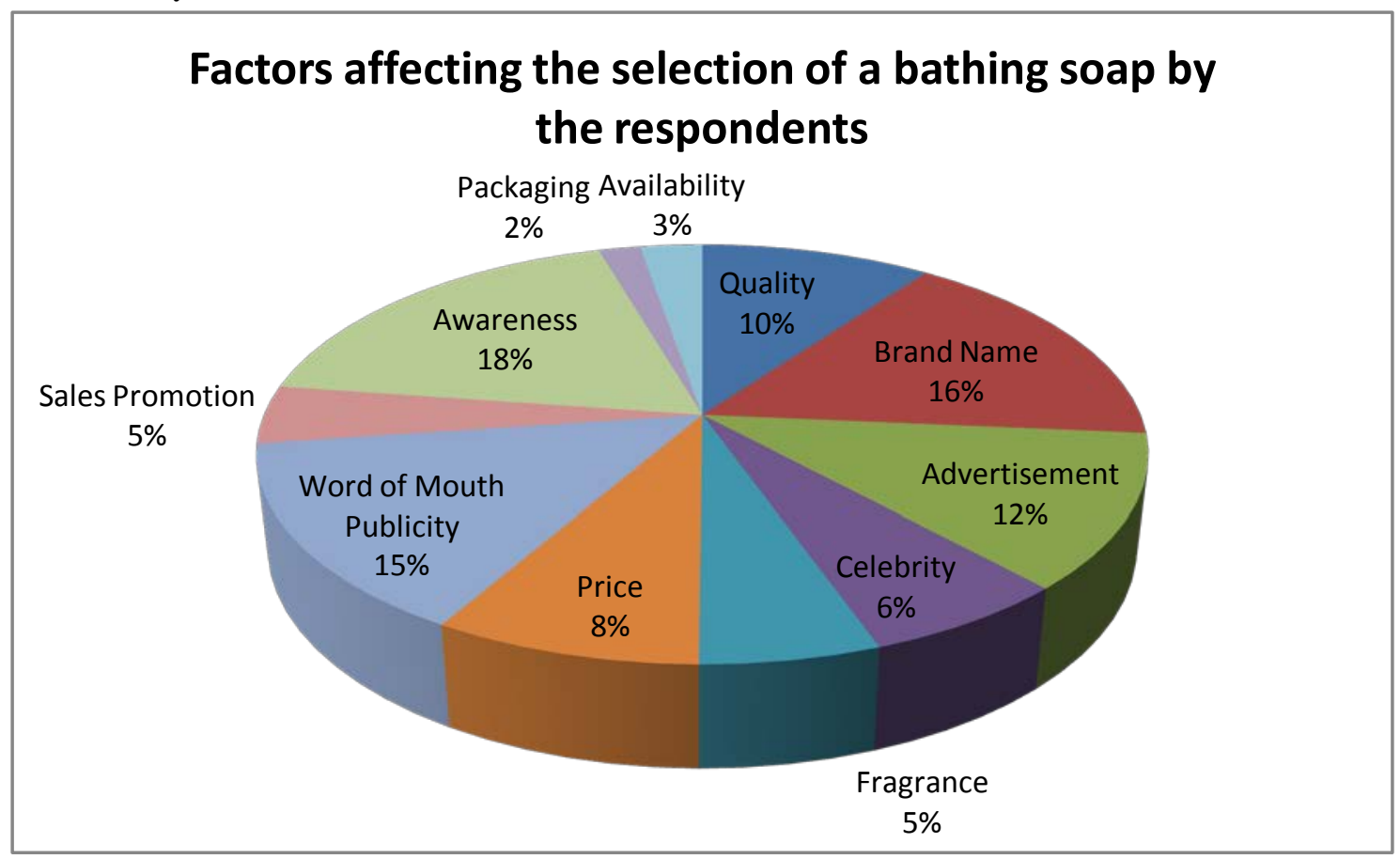

Chart 1: Chart Showing the Factors Affecting the Selection of a Bathing soap by the Respondents

Source: Survey Data

Chart 1 clearly depicts the factors that affecting the selection of a bathing soap by the respondents, that is; while selecting a particular bathing soap, customers will give much priority to the Awareness, Brand name, Word of mouth publicity, Advertisement and Quality. So a bathing soap with a well planned marketing communication with a superior awareness level along with a quality product can attract more customers towards the brand, thereby it will strengthen the word of mouth publicity thereby contributing positively towards the brand and finally it will result in the selection of a particular bathing soap.

Table 3: Table Showing the Ranking of The Factors which Influencing the Purchasing Behaviour

\begin{tabular}{|c|c|c|c|c|c|c|c|c|}
\hline Sl.No & Characteristics & Not at all important & Somewhat important & Neutral & Important & Extremely important & Total & Rank \\
\hline 1 & Celebrity & 17 & 25 & 23 & 19 & 26 & $342(7.6 \%)$ & Rank 7 \\
\hline 2 & Brand Image & 9 & 14 & 19 & 31 & 37 & 403 (9\%) & Rank 2 \\
\hline 3 & Advertisement & 16 & 23 & 22 & 20 & 29 & $353(7.9 \%)$ & Rank 6 \\
\hline 4 & Word of mouth publicity & 11 & 17 & 20 & 27 & 35 & 388 (8.6\%) & Rank 3 \\
\hline 5 & Price & 22 & 33 & 24 & 14 & 17 & $301(6.7 \%)$ & Rank 11 \\
\hline 6 & Promotion & 23 & 35 & 24 & 12 & 16 & 293 (6.5\%) & Rank 12 \\
\hline 7 & Packaging & 21 & 31 & 23 & 15 & 20 & 312 (7\%) & Rank 10 \\
\hline 8 & Fragrance & 20 & 29 & 23 & 16 & 22 & $321(7.2 \%)$ & Rank 9 \\
\hline 9 & Size & 25 & 36 & 26 & 11 & 12 & $279(6.2 \%)$ & Rank 13 \\
\hline 10 & Quality & 14 & 21 & 22 & 22 & 31 & $365(8.1 \%)$ & Rank 5 \\
\hline 11 & Awareness & 6 & 11 & 18 & 34 & 41 & 423 (9.4\%) & Rank 1 \\
\hline 12 & Parent Brand & 13 & 19 & 21 & 24 & 33 & $375(8.4 \%)$ & Rank 4 \\
\hline 13 & Ingredients & 19 & 27 & 22 & 18 & 24 & $331(7.4 \%)$ & Rank 8 \\
\hline
\end{tabular}

Source: Survey Data

Table 3 reveals the ranking of the factors which influencing the purchasing behaviour. So from the table it is evident that the awareness has the highest score and percentage (9.4\%), followed by brand image (9\%), followed by word of mouth publicity $(8.6 \%)$, followed by parent brand (8.4\%), followed by quality (8.1\%), followed by advertisement (7.9\%), followed by celebrity (7.6\%), followed by ingredients (7.4\%), followed by (fragrance $(7.2 \%)$, followed by packaging (7\%), followed by price $(6.7 \%)$, followed by promotion (6.5\%), followed by size (6.2\%). 


\section{FINDINGS}

The major findings of the study are as follows

- The demographic profile of the bathing soap customers in Ernakulam District reveals that majority of the respondents were female (64.5\%), majority of the respondents fall under the age group of 34 to 41 years $(34.5 \%)$, majority of the respondents were married (76.4\%), majority of the respondents were graduate $(37.3 \%)$, majority of the respondents were salaried persons (40.9\%) and majority of the respondents were from the income group of 2.1 lakhs to 3 lakhs (33.6\%).

- The major factors that affecting the selection of a bathing soap by the respondents, are $18.2 \%$ of respondents is of the opinion that awareness is the main factor which affects the selection of a bathing soap followed by $16.4 \%$ of respondent selected the bathing soap because of brand name followed by various factors like word of mouth publicity (14.5\%), advertisement (11.8\%), quality (10\%), price (8.2\%), celebrity $(6.4 \%)$, fragrance $(5.5 \%)$, sales promotion (4.5\%), availability (2.7\%), packaging (1.8\%).

- While selecting a bathing soap, customers give much priority to the Awareness (18.2\%), Brand name (16\%), Word of mouth publicity (15\%), Advertisement (12\%), and Quality (10\%).

- Among the factors which influence the purchasing behaviour, awareness (9.4\%) ranks highest.

- So it is evident from the study that a bathing soap with a well planned marketing communication with a superior awareness level along with a quality product can attract more customers towards the brand, thereby it will strengthen the word of mouth publicity thereby contributing positively towards the brand and finally it will result in the selection of a particular bathing soap.

\section{SUGGeStIONS}

The managers should take immense pain and care while creating marketing and promotion strategies for their products especially bathing soaps. So it is very much needed to know the mindset of consumers before doing it for making the marketing efforts in a successful manner.

So as per the study a bathing soap with a well planned marketing communication with a superior awareness level along with a quality product can attract more customers towards the brand, thereby it will strengthen the word of mouth publicity thereby contributing positively towards the brand and finally it will result in the selection of a particular bathing soap.

Thus more careful consideration must be made in framing any marketing strategies for their products.

\section{CONCLUSION}

From the light of this study it was found out that those bathing soaps with superior awareness with good brand image, followed by excellent word of mouth publicity, parent brand, quality, advertisement and right celebrity always grasp greater attention of the targeted customers. Also a bathing soap with a well planned marketing communication with a superior awareness level along with a quality product can attract more customers towards the brand, thereby it will strengthen the word of mouth publicity thereby contributing positively towards the brand and finally it will result in the selection of a particular bathing soap.

\section{SCOPE FOR FURTHER RESEARCH}

Future research should be directed to investigate more about the most important aspects that would control the consumers buying behaviour towards bathing soap. Also there is a scope for doing the same research in other parts of Kerala. The present study indicates that the consumers purchasing behaviour towards bathing soap is shaped by the factors like awareness, brand name, word of mouth publicity, advertisement, quality and many more. More investigation should be done to see that among these, which factors presume prime importance and cast exaggerated effect on the customers.

\section{REFERENCES}

[1] A.A. Kumar and S. Babu, "Factors influencing consumer buying behaviour with special reference to dairy products in Pondicherry State", International Monthly Refereed Journal of Research in Management \& Technology, Vol. 3, Pp. 65-73, 2014.

[2] K. Mahmud and K. Gope, "Factors Influencing The Extent of Brand Loyalty of Toilet Soap Users in Bangladesh", Global Journal of Management and Business Research, Vol. 12, No. 15, Pp. 24-33, 2012.

[3] G. Muruganantham and P. Biswas, "Factors Influencing the Buying Behaviour of chocolates", Journal of Management Thought and Practice, Vol. 3, No. 2, Pp. 31-42, 2011.

[4] M. Patwardhan, P. Flora and A. Gupta, "Identification of Secondary Factors that Influence Consumer's Buying Behavior for Soaps and Chocolates”, The IUP Journal of Marketing Management, Vol. 9, No. 1, Pp. 55-72, 2010.

[5] S. Saha, M. Dey and S. Bhattacharyya, "Factors Affecting Consumer Buying Behavior of Shoes in Kolkata: A Case Study", The IUP Journal of Management Research, Vol. 9, No. 4, Pp. 39-60, 2010.

[6] T. Edu, C.I. Negricea and A. Ionescu, "Consumer Behaviour patterns: Identifying buying motives for cool drinks amongst South Africans under 35 years old”, Romanian Economic and Business Review, Vol. 8, No. 1, Pp. 73-91, 2010.

[7] T. Mamatha, "Post purchase behaviour and consumerism", The ICFAIAN Journal of Management Research, No. 9, Pp. 37-67, 2008. 